NUREG/CR-5983

BNL-NUREG-52355

R8

\title{
Safety Aspects of Forced Flow Cooldown Transients in Modular High Temperature Gas-Cooled Reactors
}

Manuscript Completed: April 1993

Date Published: May 1993

Prepared by

P. G. Kroger

Brookhaven National Laboratory

Upton, NY 11973

Prepared for

Division of Systems Research

Office of Nuclear Regulatory Research

U.S. Nuclear Regulatory Commission

Washington, DC 20555

NRC FIN A3827

\section{MASTER}




\section{DISCLAIMER}

This report was prepared as an account of work sponsored by an agency of the United States Government. Neither the United States Government nor any agency Thereof, nor any of their employees, makes any warranty, express or implied, or assumes any legal liability or responsibility for the accuracy, completeness, or usefulness of any information, apparatus, product, or process disclosed, or represents that its use would not infringe privately owned rights. Reference herein to any specific commercial product, process, or service by trade name, trademark, manufacturer, or otherwise does not necessarily constitute or imply its endorsement, recommendation, or favoring by the United States Government or any agency thereof. The views and opinions of authors expressed herein do not necessarily state or reflect those of the United States Government or any agency thereof. 


\section{DISCLAIMER}

Portions of this document may be illegible in electronic image products. Images are produced from the best available original document. 
* $\div$ : 


\begin{abstract}
During some of the design basis accidents in Modular High Temperature Gas Cooled Reactors (MHTGRs), the main Heat Transport System (HTS) and the Shutdown Cooling System (SCS) are assumed to have failed. Decay heat is then removed by the passive Reactor Cavity Cooling System (RCCS) only. If either forced flow cooling system becomes available during such a transient, its restart could significantly reduce the down-time. This report uses the THATCH code to examine whether such restart, during a period of elevated core temperatures, can be accomplished within safe limits for fuel and metal component temperatures. If the reactor is scrammed, either system can apparently be restarted at any time, without exceeding any safe limits. However, under unscrammed conditions a restart of forced cooling can lead to recriticality, with fuel and metal temperatures significantly exceeding the safety limits.
\end{abstract}




\section{Contents}

Abstract $\ldots \ldots \ldots \ldots \ldots \ldots \ldots \ldots \ldots \ldots \ldots \ldots \ldots \ldots \ldots \ldots \ldots \ldots \ldots \ldots \ldots \ldots \ldots$

List of Figures $\ldots \ldots \ldots \ldots \ldots \ldots \ldots \ldots \ldots \ldots \ldots \ldots \ldots \ldots \ldots \ldots \ldots \ldots \ldots \ldots$

Executive Summary $\ldots \ldots \ldots \ldots \ldots \ldots \ldots \ldots \ldots \ldots \ldots \ldots \ldots \ldots \ldots \ldots$ vii

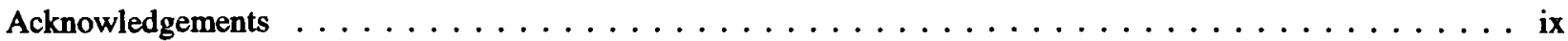

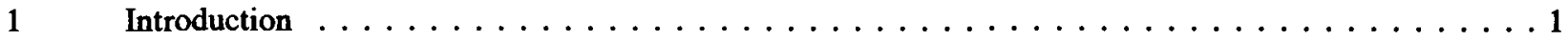

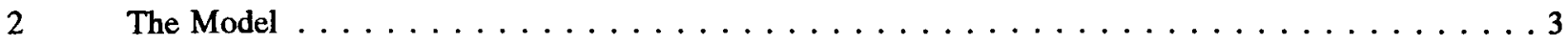

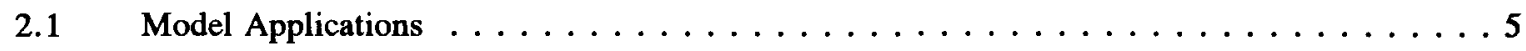

Case 1: $\quad$ SCS Restart During Pressurized Core Heatup Scenarios $\ldots \ldots \ldots \ldots$

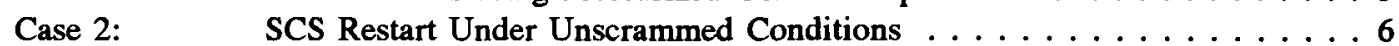

Case 3: $\quad$ HTS Restart Under Unscrammed Conditions $\ldots \ldots \ldots \ldots \ldots \ldots$



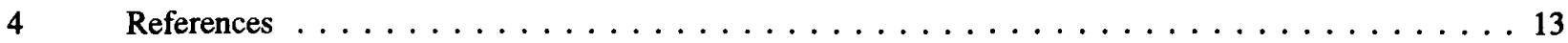




\section{List of Figures}

Page

Figure 1

Figure 2

Figure 3

Figure 4

Figure 5

Figure 6

Figure 7

Figure 8

Figure 9

Figure 10

Figure 11

Figure 12

Figure 13

Figure 14

Figure 15

Schematic of the MHTGR Primary Loop (Bechtel, 1986) $\ldots \ldots \ldots \ldots \ldots$

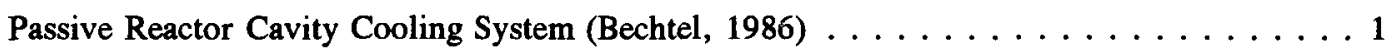

Schematic of Temperature Distribution in a Three-Region Steam Generator . . . . . . . 4

Maximum Temperatures of Active Core, Lower Bottom Reflector and Reactor

Vessel During SCS Cooldown Started After $50 \mathrm{hr}$ of a Pressurized Core

Heatup Transient . . . . . . . . . . . . . . . . . . . 5

SCS Coolant Temperatures and Upper Plenum Gas $\ldots \ldots \ldots \ldots \ldots \ldots$

Core Decay Heat Plus Fission Power During a Pressurized Core Heatup

Transient with Failure to Scram . . . . . . . . . . . . . . . 6

Active Core Temperatures During a Pressurized Core Heatup Transient with

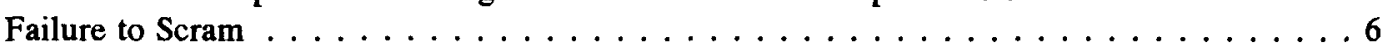

Core Reactivities During a Pressurized Core Heatup Transient with Failure

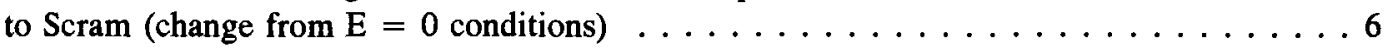

Core Power and SCS Heat Removal for SCS Restart at $40 \mathrm{hr}$ During a

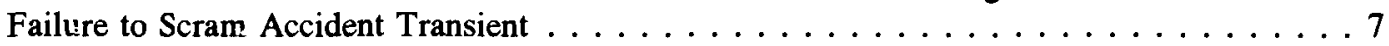

Active Core Temperatures for SCS Restart at $40 \mathrm{hr}$ During a Failure

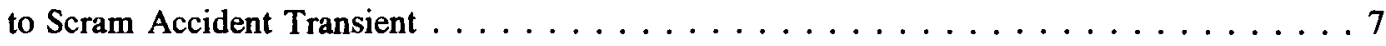

SCS Coolant Temperatures for SCS Restart at $40 \mathrm{hr}$ During a Failure

to Scram Accident Transient . . . . . . . . . . . . . . . . . 7

Active Core Temperatures for HTS Restart at $\mathbf{4 0} \mathrm{hr}$ During a Failure

to Scram Accident Transient . . . . . . . . . . . . . . . . 8

Core Power and HTS Heat Removal for HTS Restart at $40 \mathrm{hr}$ During a Failure

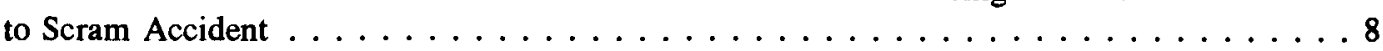

Fraction of Active Core Exceeding Specified Temperatures for HTS Restart

at $40 \mathrm{hr}$ During a Failure to Scram Accident Transient $\ldots \ldots \ldots \ldots \ldots$

HTS Coolant Temperatures for HTS Restart at $\mathbf{4 0} \mathrm{hr}$ During a Failure

to Scram Accident Transient . . . . . . . . . . . . . . . . . . 9 


\section{Executive Summary}

This report considers potential accident transients in the Modular High Temperature Gas-Cooled Reactor (MHTGR), with forced convection cooldown, using either one of the two available forced flow heat transport systems.

During the initial review of the Preliminary Safety Information Document (PSID) for this reactor, the primary focus of our investigations was on transients without forced cooling, i.e., with ultimate heat removal by the passive Reactor Cavity Cooling System (RCCS). To obtain further insight into accident scenarios with restart of the forced flow cooling systems, a new steam generator/heat exchanger module was recently added to the THATCH code. This report documents the application of these models, to analyze forced convection cooldown transients, using the main Heat Transport System (HTS) or the Shutdown Cooling System (SCS).

One of the most severe challenges to either heat transport system is a restart, during a core heat-up scenario, with passive heat rejection to the RCCS only. Following a brief presentation of the heat exchanger model several such restart transients are presented, with restart generally occurring at the time of peak core temperatures.

It was found that if the SCS becomes available during a pressurized conduction cooldown transient, even when the core temperatures are at their highest point, a restart is not expected to cause excessive temperatures in the fuel, in the metallic components of the core support structure, or in the SCS itself, assuming the reactor is scrammed.

However, if the SCS were to be started during a low probability core heat-up transient in a non-scrammed reactor, an already serious accident situation could be severely aggravated. The fuel temperatures and the coolant temperatures at the core exit could significantly exceed the respective safe temperature limits. Use of the HTS under such conditions is equally undesirable, also leading to excessive fuel and coolant temperatures. Therefore, it is quite apparent that neither forced cooling system should be activated until a safe scram has been achieved. 



\section{Acknowledgements}

During the execution of this work the author had numerous helpful and valuable discussions with Dr. Upendra S. Rohatgi at BNL.

The draft of the report was reviewed by Drs. James G. Guppy and Gregory J. Van Tuyle at BNL and by Mr. John Lane at the NRC.

Early drafts of the report were typed by Ms. Kathy Ratto. The final report was prepared by Mrs. Linda Hanlon. The author gratefully acknowledges all of the help and support he received. 


\section{Introduction}

One of the commercial advanced reactor concepts currently being developed in the United States under sponsorship of the U.S. Department of Energy (DOE) is the Modular High Temperature Gas-Cooled Reactor (MHTGR). For a detailed description of the reactor see, for instance, Bechtel, 1986. The primary loop of the MHTGR is contained in two vessels, a reactor vessel and a steam generator vessel, arranged side by side, as shown ir Figure 1. The two vessels are housed in separate cavities of an underground silo. The system has two forced convection cooldown systems, the Heat Transport System (HTS), consisting of the main circulator and steam generator, and a Shutdown Cooling System (SCS), located at the bottom of the reactor vessel. If neither of these two forced convection cooldown systems is available, the completely passive Reactor Cavity Cooling System (RCCS) can remove the decay heat and achieve final cooldown over a period of days. This system is shown schematically in Figure 2.

During the initial review of the Preliminary Safety Information Document (PSID) of this reactor, various potential accident transients were evaluated (Kroeger, 1989 and 1990), primarily using the THATCH computer code and its various sub modules (Kroeger, et al., 1991). The primary focus of these investigations was transients without forced cooling, i.e., with ultimate heat removal by the RCCS.

This report concentrates on traisients involving the forced convection cooldown systems, the HTS and the SCS. During normal power production, as well as during start-up and shut-down the HTS is used to transfer the energy, produced in the core, to the secondary coolant of the steam generator. It is designed for full power operation at $350 \mathrm{MW}$.

The primary function of the SCS - by current specification - is to provide for relatively rapid reactor cooldown, in about 24 hours, in case the HTS is not available. Thus, the SCS serves primarily to reduce down time due to unavailability of the HTS. It is designed for decay heat removal at a rate of about 24 MW.

This paper will apply a new steam generator/heat exchanger module of the THATCH code (Kroeger and Kennett, 1991) to some accident scenarios of potential concern. There is little doubt that either forced flow heat removal system can safely cool down the reactor from full power, if available at the beginning of a shut down transient. However, during passive conduction cooldown

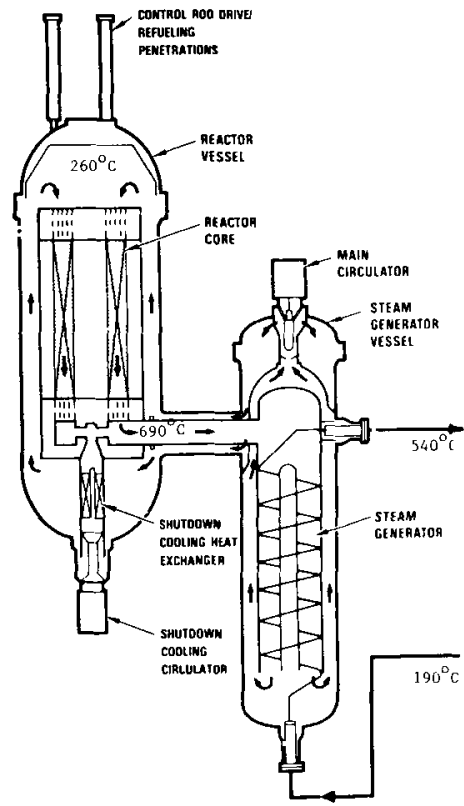

Figure 1 Schematic of the MHTGR Primary Loop (Bechtel, 1986)

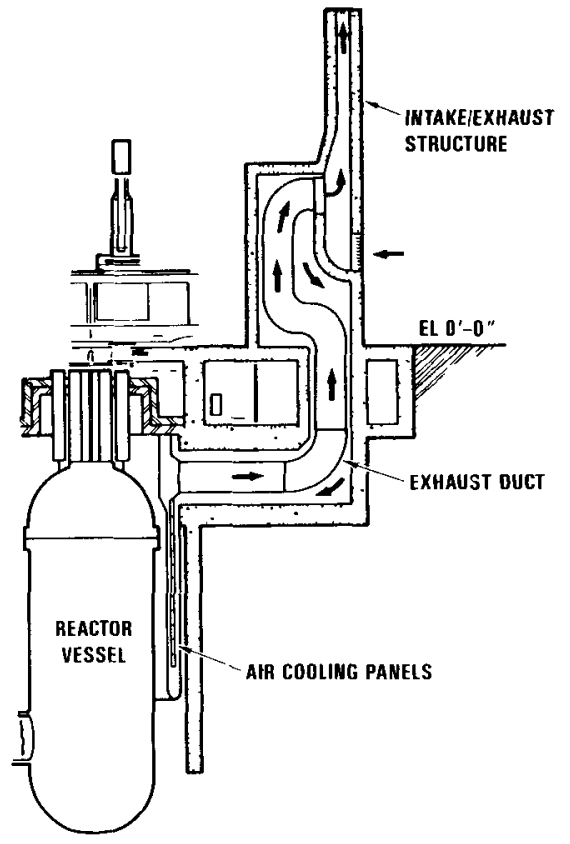

Figure 2 Passive Reactor Cavity Cooling System (Bechtel, 1986) 


\section{Introduction}

via the RCCS, peak core temperatures of about $1400^{\circ} \mathrm{C}$ can be expected. If either of the two forced convection systems were started during such a core cooldown transient, hotter than usual gas could enter the metallic sections of the core support structure or of the heat removal system, potentially causing component damage. In the low probability case of loss of forced circulation without scram, the reactor shuts down and remains subcritical due to the negative core temperature feedback and due to xenon build up. However, a start of the SCS under such conditions would reduce core temperatures and could increase reactivity and core heat generation. These abnormal events are the primary concern of this paper. 


\section{The Model}

The steam generator/heat exchanger model applied here solves the quasi-steady energy balance in a heat exchanger, allowing for phase change on the secondary side.

Under normal circumstances the SCS heat exchanger is a single phase counterflow heat exchanger with helium on the shell side and water on the tube side. By control of the SCS circulator, speed the water-side outlet temperature is kept constant, providing sufficient margin from boiling.

The HTS steam generator consists of economizer, evaporator and superheater sections, again with the primary loop coolant, helium, on the shell side and the water or steam on the tube side. While the above three regions exist under normal operating conditions, only one or two regions may be present under start-up and shutdown conditions, or during some accident transients. The flow arrangement is counterflow here too, with helium downflow and water upflow.

Based on the given coolant flows, the inlet temperatures, and the available heat transfer surface, the model tests whether the secondary side water outlet conditions will be liquid, vapor or superheated vapor, and analyzes the performance as a single-region, two-region or threeregion heat exchanger, as appropriate. If the number of regions exceeds those anticipated, a warning alerts the user.

For a counterflow heat phase the following energy balance applies for regions 1 and 3, following the schematic of Figure 3:

$$
\mathrm{dQ}_{\mathrm{i}}=\mathrm{W}_{\mathrm{a}} \mathrm{c}_{\mathrm{ps}} \mathrm{d} \theta_{\mathrm{s}}=\mathrm{W}_{\mathrm{h}} \mathrm{c}_{\mathrm{ph}} \mathrm{d} \theta_{\mathrm{h}}
$$

and

$$
d Q_{i}=U_{i}\left(\theta_{h}-\theta_{s}\right) d A
$$

where $Q_{i}$ is the heat transferred in Region i, $\theta$ is the temperature, $W$ is the mass flow, $c_{p}$ is the specific heat, $\mathrm{U}_{\mathrm{i}}$ is an overall heat transfer coefficient, and $\mathrm{A}$ is the heat transfer surface area. The subscript $h$ designates helium and $s$ water or steam. Defining

$$
\psi_{i}=\frac{U_{i} A_{i}}{W_{b} c_{p h}}
$$

and

$$
\lambda_{i}=\frac{W_{b} c_{p h}}{\left(W_{s} c_{p s}\right)_{i}}
$$

Equations (1) and (2) can be integrated over a single phase region and yield

$$
\theta_{\mathrm{hi}}-\theta_{\mathrm{hi}-1}=\mathrm{E}_{\mathrm{i}}\left(\theta_{\mathrm{hj}}-\theta_{\mathrm{i} i-1}\right)
$$

and

$$
\theta_{\mathrm{si}}-\theta_{\mathrm{s} i-1}=\lambda\left(\theta_{\mathrm{hi}}-\theta_{\mathrm{h} i-1}\right)
$$

where for $\lambda_{i} \neq 1$

$$
E_{i}=\frac{1-e^{-\psi_{1}\left(\lambda_{1}-1\right)}}{\lambda_{i}-e^{-\psi_{i}\left(\lambda_{i}-1\right)}}
$$

and for the special case $\lambda_{i}=1$

$$
E_{i}=\frac{\psi_{i}}{1+\psi_{i}}
$$

In the evaporator section (region 2) one obtains from the above energy balance with the water side temperature remaining constant

$$
\theta_{\mathrm{h} 2}-\theta_{\mathrm{h} 1}=\left(1-\mathrm{e}^{-\downarrow_{2}}\right)\left(\theta_{\mathrm{h} 2}-\theta_{\mathrm{a} 1}\right)
$$

and

$$
\theta_{\mathrm{h} 2}-\theta_{\mathrm{h} 1}=\frac{\mathrm{W}_{\mathrm{g}} \mathrm{h}_{\mathrm{fg}}}{\mathrm{W}_{\mathrm{b}} \mathrm{c}_{\mathrm{ph}}}
$$




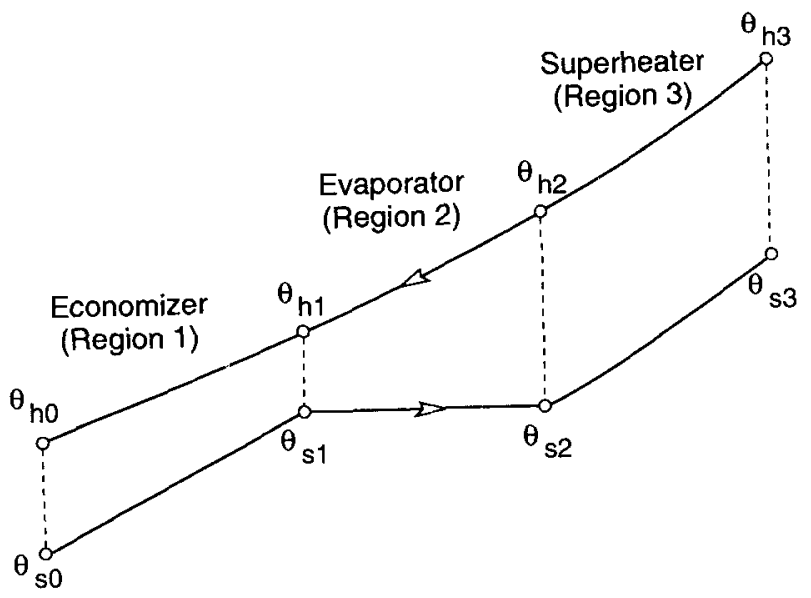

Figure 3 Schematic of Temperature Distribution in a Three-Region Steam Generator

In the current MHTGR design, both the HTS and the SCS use helical coil tube bundles, with the primary coolant on the shell side and the secondary coolant on the tube side. The overall heat transfer coefficient $U_{i}$ is the combined coefficient for tube side, tube wall and shell side heat transfer resistances. On the shell side the correlations of Section 2.5.3 of the Heat Exchanger Design Handbook (Schlunder, 1983) are used for flow across in-line unfinned tube banks.

The helium side generally constitutes the dominant heat transfer resistarice. However, for the feedwater heater and the superheater sections the tube wall conduction and the secondary side heat transfer are also evaluated. In the evaporator section the tube wall and secondary side resistances are currently neglected. The secondary side heat transfer coefficients for the subcooled and superheated regions are computed from the correlations of Section 2.5.14 of the Heat Exchanger Design Handbook (Schlunder, 1983) for flow inside of helically coiled tubes.

Equations (5) and (6) can be solved for given flow rates, inlet temperatures and heat transfer surfaces for the two coolant exit temperatures of any single phase region. In case of a single phase heat exchanger an iterative solution of these equations, considering the temperature dependence of $E_{i}$ and $\lambda_{i}$ is obtained by the code, applying a Newton Raphson procedure.

In the three region case of economizer, evaporator and superheater, Equation (5) for Regions 1 and 3 and Equation (9) for Region 2 are three equations characterizing the heat transfer in these three regions. They are symbolically designated as $H_{i}$, where $i$ is the number of the region. Equations (6) for Regions 1 and 3 and (10) for Region 2 comprise a set of three energy balance equations, symbolically designated as $B_{i}$. Note that in addition to coolant inlet and exit temperatures of each region, the heat transfer surface area of the region $A_{i}$ is an additional unknown, since only the total heat transfer surface $A_{T}$ is known.

Considering the sum of heat transfer surfaces

$$
\sum_{i=1}^{n} A_{i}=A_{r}
$$

where $\mathbf{n}$ is the number of regions present, the set of Equations $H_{1}$ to $H_{3}$ and $B_{1}$ to $B_{3}$ combined with Equation (11) constitutes a set of seven simultaneous non-linear algebraic equations in the seven variables $A_{1}, A_{2}, A_{3}$ and $\theta_{\mathrm{h} 2}, \theta_{\mathrm{b} 1}, \theta_{\mathrm{b} 0}, \theta_{\mathrm{s} 3}$. The set of simultaneous equations is solved again, using a Newton-Raphson procedure after algebraic elimination of some of the equations.

For the case of only two regions being present (economizer and evaporator) an equivalent procedure is applied. In this case Equation (10) can be expressed as

$$
\theta_{\mathrm{h} 2}-\theta_{\mathrm{h} 1}=\frac{\mathrm{W}_{\mathrm{s}} \mathrm{h}_{\mathrm{fg}} \mathrm{x}}{\mathrm{W}_{\mathrm{h}} c_{\mathrm{ph}}}
$$

where $\mathrm{x}$ designates the steam exit quality. Homogeneous equilibrium, i.e., both phases moving at equal velocities, is assumed here.

During HTS transients the regions present in the steam generator may change, depending on coolant flow rates and inlet temperatures. The code will therefore, optionally, check how many regions can be present under current inlet conditions and will flag any changes in the number of regions from the preceding call, as well as 
unexpectedly high region numbers (like boiling in the SCS).

\subsection{Model Applications}

At this time, some details of the design data, affecting performance, have not been finalized. Estimates and/or scaling were, therefore, applied for some of these data, such as the SCS tube bundle diameter. The current results are, therefore, preliminary, and will be revised as more details become available. However, they are sufficient to indicate overall behavior and trends.

General HTS and SCS shutdown transients were analyzed and have been presented with the model documentation (Kroeger and Kennett, 1991). Some potential accident scenarios will be presented here.

\section{Case 1: SCS Restart During Pressurized Core Heatup Scenarios}

During a typical "conduction cooldown", which is a reactor transient following loss of forced cooling with scram, heat is initially stored in the core with slow heat rejection to the RCCS. Current best estimate evaluations of pressurized core heatup transient indicate peak fuel temperatures of $1210^{\circ} \mathrm{C}$ at $46 \mathrm{hr}$, and peak vessel temperatures of $380^{\circ} \mathrm{C}$ at $80 \mathrm{hr}$.

To reduce the down time following such scenarios, one would want to start the SCS whenever it is available. However, starting it while the core temperatures are at elevated levels could, in principle, expose metallic parts of the core support structure and the SCS to excessive gas temperatures. To investigate such a scenario, a pressurized core heatup transient with an SCS start-up at $50 \mathrm{hr}$ was analyzed.

Core and vessel temperatures for the SCS cooldown portion of the transient are shown in Figure 4. Coolant temperatures are shown in Figure 5. The peak core temperatures of about $1200^{\circ} \mathrm{C}$ occur in the upper parts of the active core, while the bottom reflectors are at about 400 to $500^{\circ} \mathrm{C}$ at the beginning of SCS cooldown. The coolant exiting the bottom of the core and passing to the SCS initially gets hotter and reaches a maximum temperature of about $700^{\circ} \mathrm{C}$ about 20 minutes after the beginning of SCS cooldown. With $700^{\circ} \mathrm{C}$ being the core exit temperature during normal full power operation, this does not impose any excessive temperatures on the SCS or the core support structure. The temperature rise between SCS helium exit temperature and upper plenum temperature in Figure 5 indicates cooling of core barrel and vessel by the upflowing helium. The SCS water



Figure 4 Maximum Temperatures of Active Core, Lower Bottom Reflector and Reactor Vessel During SCS Cooldown Started After 50 hr of a Pressurized Core Heatup Transient

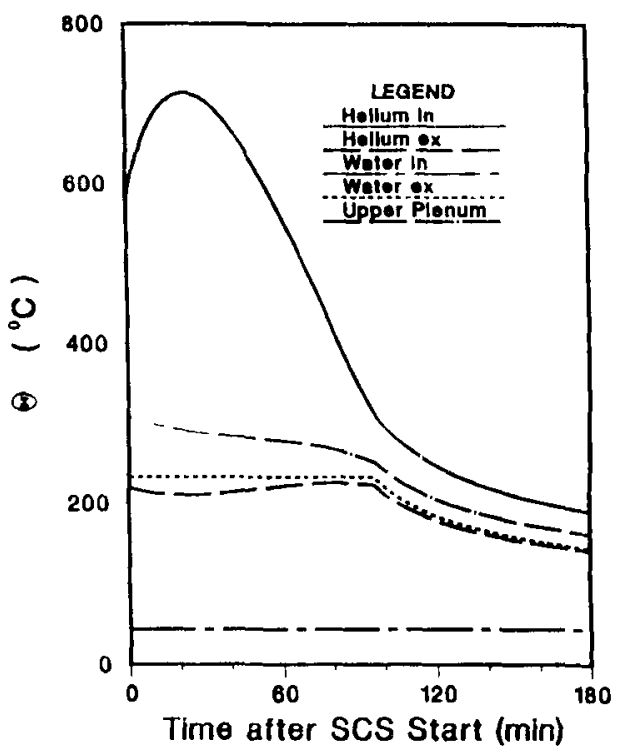

Figure 5 SCS Coolant Temperatures and Upper Plenum Gas 
The Model

outlet temperature remains initially constant, as the SCS control logic adjusts the helium flow to achieve a constant heat removal rate. The assumed maximum circulator speed is reached about 100 minutes after start of the SCS. Because the primary coolant flow no longer increases, the water exit temperature and the total heat removal rate begin to decrease. Thus, this preliminary analysis indicates that SCS startup during a pressurized core heatup transient does not appear to impose any risk to the metallic reactor components.

\section{Case 2: SCS Restart Under Unscrammed Conditions}

The MHTGR has two independent scram systems, and a loss of forced cooling combined with failure to scram is an event of very low probability. Such scenarios have been investigated during the PSID review (Kroeger, 1989). It was found that in case of loss of forced cooling plus failure to scram, the reactor will become subcritical due to its negative temperature feedback coefficient. This is initially supplemented by increasing xenon concentration. However, as the xenon decays recriticality occurs and power oscillations at low power levels are observed after about $40 \mathrm{hr}$, as shown here for current conditions in Figures 6 and 7. Associated with these low power oscillations, an increase in peak core temperatures can be observed. Typical reactivities for such a scenario are shown in Figure 8. After about 42 hours, the xenon has decayed below full power levels, so its net impact on reactivity becomes "positive" (less negative than at the beginning of the process). To compensate, the core heats up and a quasi-equilibrium is established with about $2 \mathrm{MW}$ of fission power.



Figure 6 Core Decay Heat Plus Fission Power During a Pressurized Core Heatup Transient with Failure to Scram

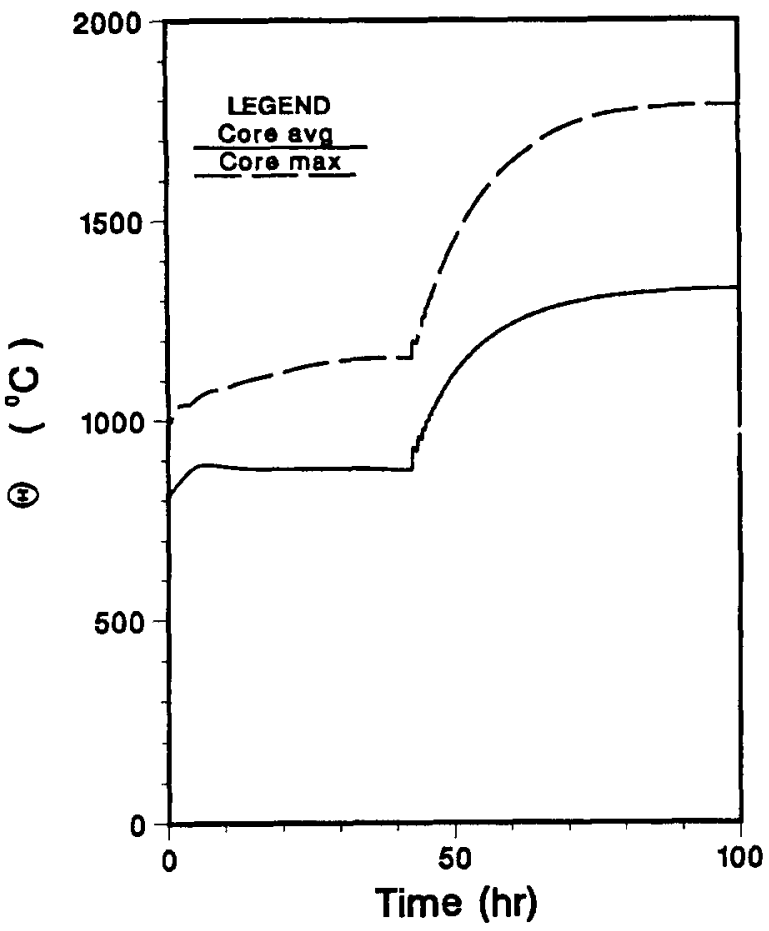

Figure 7 Active Core Temperatures During a Pressurized Core Heatup Transient with Failure to Scram

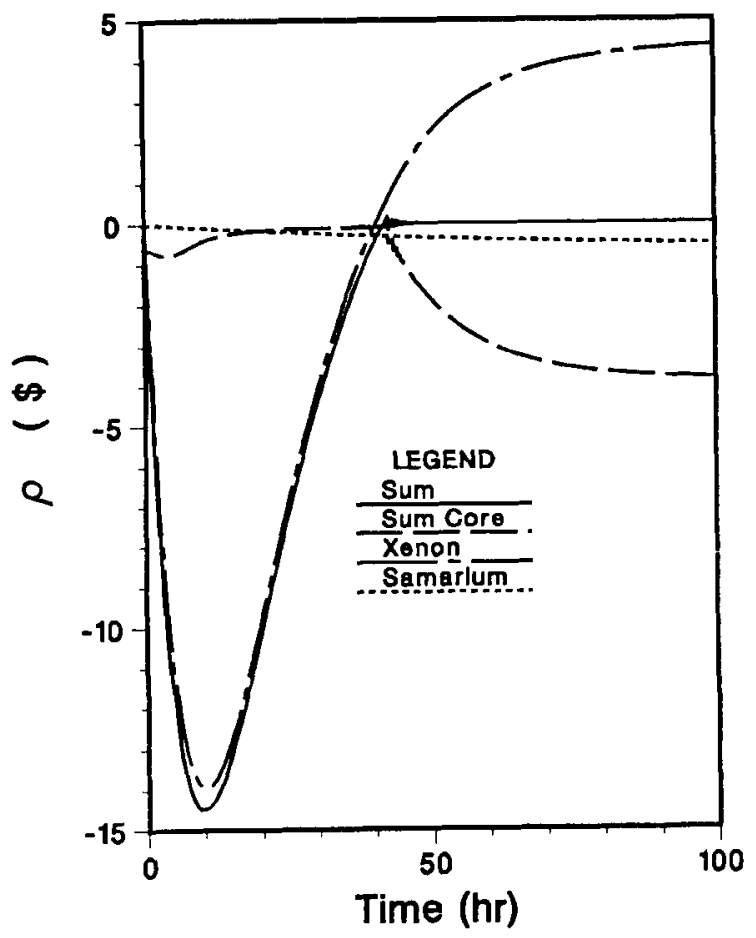

Figure 8 Core Reactivities During a Pressurized Core Heatup Transient with Failure to Scram (change from $\mathbf{E}=\mathbf{0}$ conditions) 
Thus, if the SCS were to be started under such unscrammed conditiors its cooling of the core could aggravate an already serious accident condition. Typical results for an assumed SCS restart at $40 \mathrm{hr}$, i.e. shortly before recriticality, are shown in Figures 9 to 11.

Shortly after SCS restart initial power oscillations are observed, until a fission plus decay heat power level of about $28 \mathrm{MW}$ is established, with about $24 \mathrm{MW}$ heat removal by the SCS. While the average core temperature for this case is less than in the no-scram scenario without SCS restart, the maximum core temperatures are significantly higher, reaching $1900^{\circ} \mathrm{C}$ at about $58 \mathrm{hr}$. About $10 \mathrm{hr}$ after the SCS restart, $30 \%$ of the fuel exceeds the safe temperature limit of $1600^{\circ} \mathrm{C}$. In the original scenario of failure to scram without SCS restart, only $15 \%$ of the core exceeded $1600^{\circ} \mathrm{C}$ with a maximum core temperature at $70 \mathrm{hr}$ of $1730^{\circ} \mathrm{C}$. The helium coolant leaving the lower plenum reaches temperatures above $1000^{\circ} \mathrm{C}$ within about $2 \mathrm{hr}$ of SCS restart, which is an excessive level for the metallic core support structure and the SCS components. Similar scenarios, considering SCS restarts at $20 \mathrm{hr}$ and at $50 \mathrm{hr}$, gave equivalent results of excessive peak fuel temperatures and helium coolant temperatures.



Figure 9 Core Power and SCS Heat Removal for SCS Restart at $\mathbf{4 0}$ hr During a Failure to Scram Accident Transient
The Model

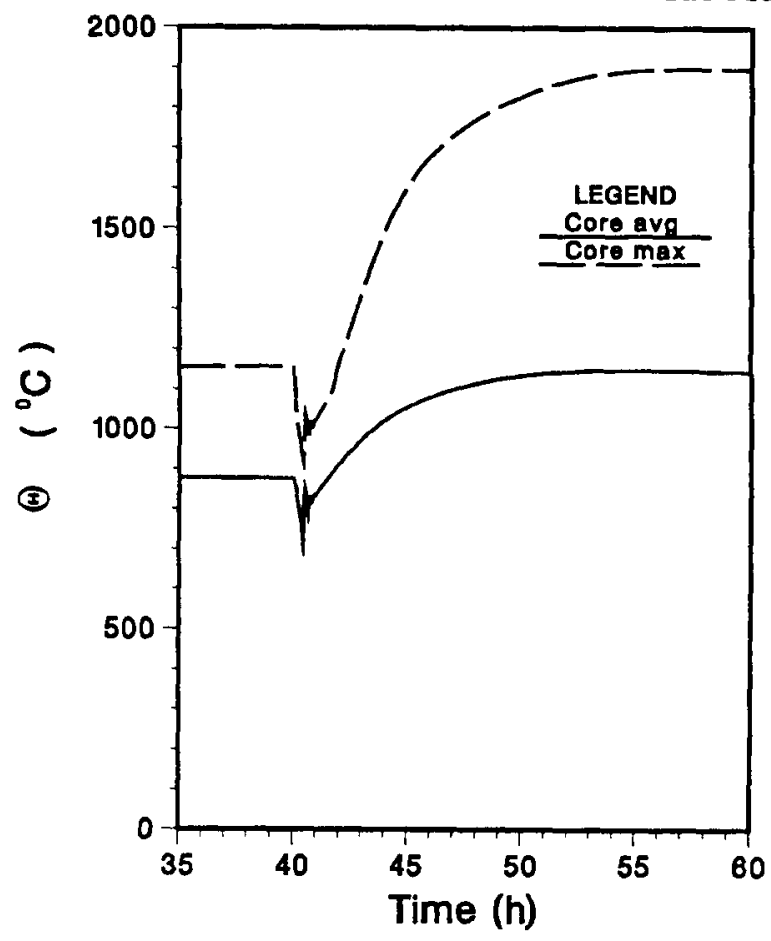

Figure 10 Active Core Temperatures for SCS Restart at $\mathbf{4 0} \mathrm{hr}$ During a Failure to Scram Accident Transient

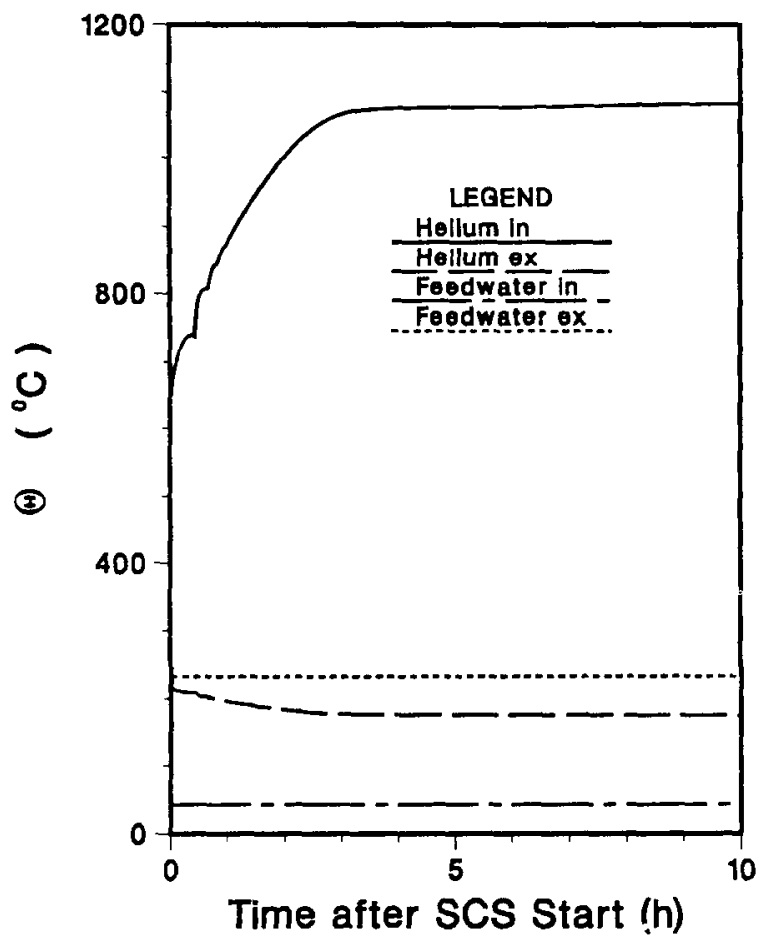

Figure 11 SCS Coolant Temperatures for SCS Restart at $\mathbf{4 0} \mathrm{hr}$ During a Failure to Scram Accident Transient 
The Model

Case 3: HTS Restart Under Unscrammed Conditions

An HTS restart at $40 \mathrm{hr}$, i.e., shortly before recriticality, was also modelled. Results are shown in Figures 12 to 15. After an initial brief cooldown period, at about $40.08 \mathrm{hr}$, the next xenon contribution to reactivity becomes positive, resulting in recriticality, forcing the core to heat up. The core temperature would rise relatively rapidly in such a scenario, and around $42 \mathrm{hr}$ peak fuel temperatures close to $1800^{\circ} \mathrm{C}$ would be reached. About $15 \%$ of the active core would exceed the safe temperature limit of $1600^{\circ} \mathrm{C}$ for about $5 \mathrm{hr}$. However, worst of all, coolant temperatures to the HTS would reach $1500^{\circ} \mathrm{C}$, an unacceptable level, and early failure of the steam generator or circulator would be expected. Thus, in the remote case of a core heatup transient without scram, one would not want to start either forced cooling system until scram, via either one of the two scram systems, has been achieved.



Figure 12 Active Core Temperatures for HTS Restart at $\mathbf{4 0}$ hr During a Failure to Scram Accident Transient

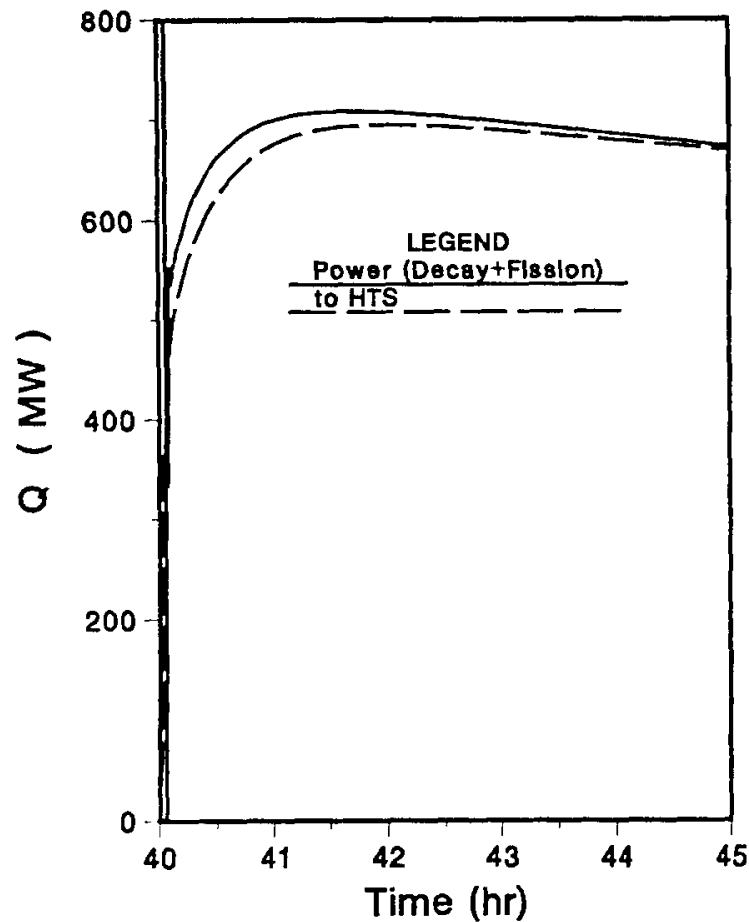

Figure 13 Core Power and HTS Heat Removal for HTS Restart at $\mathbf{4 0} \mathrm{hr}$ During a Failure to Scram Accident

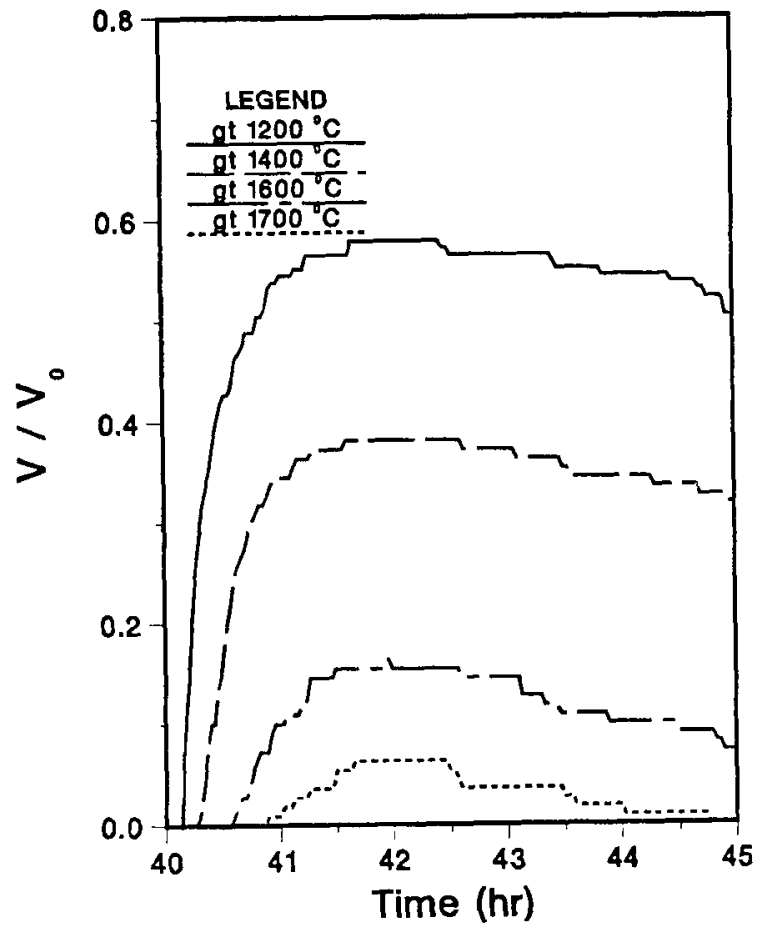

Figure 14 Fraction of Active Core Exceeding Specified Temperatures for HTS Restart at $40 \mathrm{hr}$ During a Failure to Scram Accident Transient 




The Model

Figure 15 HTS Coolant Temperatures for HTS Restart at $\mathbf{4 0}$ hr During a Failure to Scram Accident Transient 
$$
\text { . }
$$ 


\section{Conclusions}

A new heat exchanger/steam generator module for the THATCH code has been applied to several postulated MHTGR accident transients. It was found that if the SCS becomes available during a pressurized conduction cooldown transient, it can be started, even during the time period of highest core temperatures, without causing excessive temperatures in the fuel or in the metallic components of the core support structure or the SCS itself, assuming the reactor has been shut down.

If the SCS were to be used during a low probability core heatup transient in a non-scrammed reactor, an already serious accident situation would be severely aggravated. Peak fuel temperatures would increase significantly, to about $1900^{\circ} \mathrm{C}$, and the helium coolant leaving the core could exceed temperatures of $1000^{\circ} \mathrm{C}$. Use of the HTS under such conditions is equally undesirable, leading to fuel temperatures close to $1800^{\circ} \mathrm{C}$ and, worst of all, to coolant temperatures above $1500^{\circ} \mathrm{C}$.

Therefore, it is quite apparent that neither forced cooling system should be activated until a safe scram has been achieved. 
$$
\text { . }
$$ 


\section{References}

Bechtel National, Inc. et al., "HTGR Concept

Description Report, Reference Modular High

Temperature Gas Cooled Reactor Plant", Report DOE-

HTGR-86-118, October 1986.

P. G. Kroeger, "Safety Evaluation of MHTGR Licensing

Basis Accident Scenarios", Brookhaven National

Laboratory, NUREG/CR-5261, BNL-NUREG-52174,

April 1989.

P. G. Kroeger, "Safety Evaluations of Accident Scenarios in High Temperature Gas-Cooled Reactors", Nuclear Engineering and Design, Vol. 122, 1990, p. $443-452$.

P. G. Kroeger, R. J. Kennett, J. Colman, T. Ginsberg, "THATCH: A Computer Code for Modelling Thermal Networks of High Temperature Gas-Cooled Reactors", Brookhaven National Laboratory, NUREG/CR-5620, BNL-NUREG-52297, September 1990.

P. G. Kroeger, R. J. Kennett, "Code and Model Extensions of the THATCH Code for Modular High Temperature Gas-Cooled Reactors", Brookhaven National Laboratory, NUREG/CR-5620, BNL-NUREG-52356, March 1993.

E. U. Schlunder, ed., Heat Exchanger Design Handbook, Hemisphere Publishing Co., New York, 1983. 